\title{
Steroid metabolism in corpora lutea of the western spotted skunk (Spilogale putorius latifrons)*
}

\author{
R. Ravindra, Kiran Bhatia and R. A. Mead \\ Department of Biological Sciences, University of Idaho, Moscow, Idaho 83843, U.S.A.
}

\begin{abstract}
Summary. The present study reports steroid metabolism by corpora lutea (CL) obtained from skunks with diapausing embryos ('delay' $C L$ ) and with activated embryos (activated CL). CL from both reproductive periods were incubated with various radioactive precursors. Control incubations without any tissue or with $50 \mu$ l of packed skunk blood cells were also conducted simultaneously. Incubation of skunk $\mathrm{CL}$ with $\left[{ }^{3} \mathrm{H}\right]-$ pregnenolone for $3 \mathrm{~h}$ resulted in $36 \%$ of the precursor accumulating as progesterone. Metabolism of $\left[{ }^{3} \mathrm{H}\right]$ dehydroepiandrosterone (DHEA) to androstenedione proceeded with approximately the same amount of product accumulating (34-46\%) as was observed in the conversion of pregnenolone to progesterone. These results suggest that $\Delta^{5}$ isomerase, $3 \beta$-hydroxysteroid dehydrogenase, is the most prominent enzyme in skunk CL. Metabolism of $\left[{ }^{3} \mathrm{H}\right]$ pregnenolone to $17 \alpha$-hydroxypregnenolone and $\left[{ }^{3} \mathrm{H}\right]$ progesterone to $17 \alpha$-hydroxyprogesterone occurred at low rates $(1-7 \%)$, suggesting the presence of $\mathrm{C}_{21}$ steroid $17 \alpha$-hydroxylase in skunk CL. Aromatase activity, as estimated by measuring accumulation of oestradiol- $17 \beta$ from $\left[{ }^{3} \mathrm{H}\right]$ testosterone, was demonstrated in activated $\mathrm{CL}$. These results suggest that skunk $\mathrm{CL}$ appear to metabolize steroids in a manner similar to CL of other mustelids such as the ferret and American badger.
\end{abstract}

\section{Introduction}

The western spotted skunk has an unusual reproductive cycle. It breeds in late September and early October and shortly thereafter the embryos enter the uterus, embryonic development becomes arrested and blastocyst implantation is delayed for 200-220 days (Mead, 1968, 1981). This arrest in embryonic development is accompanied by incomplete luteinization of most granulosa cells and low plasma progesterone concentrations (Sinha \& Mead, 1975). Luteal development is renewed a few days before implantation and is temporally correlated with blastocyst expansion (period of embryonic activation) and increased progesterone secretion (Sinha \& Mead, 1975; Mead, 1981). However, implantation cannot be induced by administering progesterone to ovariectomized skunks (Mead, Concannon \& McRae, 1981) or other mustelids (Mead, 1981), although the corpora lutea (CL) appear to be the source of hormones which induce implantation in these mustelids. This theory is supported by the observation that $\mathrm{CL}$ are the only ovarian compartment in the spotted skunk which exhibit striking morphological and cytological changes that are temporally correlated with embryonic development and implantation (Mead \& Eik-Nes, 1969; Mead, 1981). Moreover, implantation can be induced in ovariectomized mustelids, such as the ferret and mink, bearing ectopic CL but not by progesterone (Foresman \& Mead, 1978; Murphy, Mead \& McKibbin, 1983). It would therefore appear that the CL of these species are secreting another compound which acts in conjunction with progesterone to induce implantation. This possibility was investigated in the present study of steroid metabolism of skunk CL.

\footnotetext{
* Reprint requests to Dr R. A. Mead.
} 


\section{Materials and Methods}

Wild female western spotted skunks (Spilogale putorius latifrons), captured between 1 November and 30 January, were purchased from a trapper in Oregon. The skunks were caged individually in a room illuminated by environmental light only and supplied ad libitum with dried dog food and water. The CL from 22 skunks were collected between 29 January and 15 March (period of embryonic diapause), i.e. about 81-36 days before the average date of implantation (20 April). Activated CL, which were larger in size and weight than those obtained during delayed implantation, were obtained from another 25 females. Increased blastocyst diameter was also used as a criterion that blastocyst implantation was impending. All animals were anaesthetized with pentobarbitone sodium $(40 \mathrm{mg} / \mathrm{kg}$ ) and a blood sample was taken by cardiac puncture. The ovaries were removed, the $\mathrm{CL}$ dissected free of any adhering follicles or interstitial tissue and placed in medium TC- 199 at $4^{\circ} \mathrm{C}$. Only CL from skunks possessing unimplanted blastocysts, which were flushed from the uterus and measured with a calibrated ocular micrometer, were used. The CL were then quartered, pooled and weighed into $7.5 \mathrm{mg}$ samples.

The steroids used were $\left[{ }^{3}-{ }^{3} \mathrm{H}\right]$ pregnenolone (sp. act. $10 \mathrm{Ci} / \mathrm{mmol}$ : Amersham International, Bucks, U.K.), [1,2-3 H]progesterone (sp. act. $57 \mathrm{Ci} / \mathrm{mmol}$ : New England Nuclear, MA, U.S.A.), $\left[1,2,6,7-{ }^{3} \mathrm{H}\right]$ dehydroepiandrosterone (DHEA) (sp. act. $64 \mathrm{Ci} / \mathrm{mmol}$ : Amersham) and $[1,2,6,7,16,17-$ ${ }^{3} \mathrm{H}$ ]testosterone (sp. act. $135 \mathrm{Ci} / \mathrm{mmol}$ : New England Nuclear). All tritiated precursors were purified 1 day before use as described by Kintner \& Mead (1983). The samples of luteal tissue were incubated with $5 \mu \mathrm{Ci}$ of one of the above radiolabelled precursors for $10,30,60$ or $180 \mathrm{~min}$ at $37^{\circ} \mathrm{C}$, in $3 \mathrm{ml}$ of Krebs-Ringer-bicarbonate (KRB) buffer $\mathrm{pH} 7 \cdot 1$ in an atmosphere of $95 \%$ air :5\% $\mathrm{CO}_{2}$. Control incubations with the same amount of radiolabelled steroid were conducted in flasks containing KRB buffer without tissue. Another control consisted of $50 \mu$ packed skunk blood cells which were also incubated in KRB buffer. The incubations were stopped by the addition of $5 \mathrm{ml}$ ethyl acetate.

Tissue homogenization, extraction, addition of authentic labelled steroids to monitor recovery, paper chromatography to separate the various steroid complexes (oestradiol and $17 \alpha$-hydroxypregnenolone, oestrone and androstenediol, 17 $\alpha$-hydroxyprogesterone and testosterone, 20 $\alpha$ dihydroprogesterone, DHEA and androstenedione, and $5 \alpha$-dihydroprogesterone and progesterone), thin-layer chromatography (t.l.c.) to isolate individual steroids, and quantitation were identical to those described by Kintner \& Mead (1983) with the following exceptions.

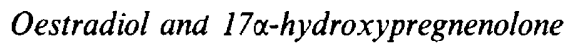

After eluting this steroid complex from paper chromatograms, an appropriate amount of $\left[{ }^{14} \mathrm{C}\right]-$ oestradiol was added to monitor recovery. Due to the lack of a labelled $17 \alpha$-hydroxypregnenolone standard, recovery of this steroid was estimated on the basis of the average loss expected for each step involved in the isolation process. Initial separation of these steroids was achieved by t.l.c. (benzene : diethyl ether, $3: 1 \mathrm{v} / \mathrm{v}$ ). The $17 \alpha$-hydroxypregnenolone was acetylated and the products were extracted, chromatographed, and quantitated as described by Kintner \& Mead (1983). Oestradiol was methylated (Brown, 1955) and the methyl ether of oestradiol was isolated by t.l.c. (benzene :methanol, $95: 5 \mathrm{v} / \mathrm{v}$ ) and quantitated by liquid scintillation spectrometry.

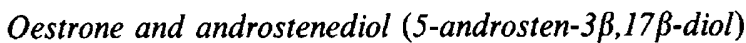

These were separated by t.l.c. (chloroform :ether, $4: 1 \mathrm{v} / \mathrm{v}$ ). Recovery of androstenediol was monitored by processing additional tubes containing authentic tritiated and unlabelled androstenediol whereas $\left[{ }^{14} \mathrm{C}\right]$ oestrone was added directly to each sample after elution from the paper to monitor recovery of oestrone. Oestrone was methylated (Brown, 1955), the methyl ether was isolated by t.l.c. (benzene:methanol, $95: 5 \mathrm{v} / \mathrm{v}$ ) and quantitated by liquid scintillation 
spectrometry. Androstenediol was acetylated, isolated and quantitated as described by Kintner \& Mead (1983).

Aliquants of each major radioactive steroid product obtained from luteal samples were pooled and stored at $4^{\circ} \mathrm{C}$ until further use. Then $100000-250000$ c.p.m. of the ${ }^{3} \mathrm{H}$-products were mixed with 25-35 mg of the appropriate authentic steroid and recrystallized up to 5 times. Dried samples of each set of crystals were weighed on a Cahn electrobalance and counted in a liquid scintillation spectrometer. The steroid was considered radiochemically pure if three successive sets of crystals had specific activities within a $5 \%$ deviation about the mean.

All values are reported as the percentage of initial ${ }^{3} \mathrm{H}$-labelled precursor metabolized to each steroid. Results of all incubations were first statistically analysed by analysis of variance. Significant differences between means were subsequently determined using least squares means. Values were considered significantly different if $P<0.05$.

\section{Results}

Blastocysts from skunks exhibiting embryonic diapause averaged $0.9 \mathrm{~mm}$ in diameter $(0.7-1.1 \mathrm{~mm})$ and the mean weight of each CL was $2.7 \mathrm{mg}$; whereas activated blastocysts from skunks averaged $1.4 \mathrm{~mm}(1.2-2.0 \mathrm{~mm})$ and the mean weight of each CL was $5.6 \mathrm{mg}$.

Activated $\mathrm{CL}$ and those in delay metabolized $\left[{ }^{3} \mathrm{H}\right]$ pregnenolone to other steroids to approximately the same extent (Table 1). Depending upon the techniques used for separation, the average recoveries for the different steroids ranged from 46 to $76 \%$. About $36 \%$ of the total radioactivity added accumulated as progesterone after $180 \mathrm{~min}$ of incubation $(P<0.05)$ during both stages of pregnancy. Only small $(<3 \%)$ but statistically significant $(P<0.05)$ amounts of $17 \alpha-$ hydroxypregnenolone and androstenedione accumulated during the course of 3-h incubations of both types of CL (Table 1). Small amounts of label were likewise incorporated into testosterone by 'delay' CL. However, the amounts of $17 \alpha$-hydroxyprogesterone and DHEA which accumulated during incubations for 10-180 min were not statistically different from control incubations containing plain buffer or packed blood cells (data not shown). Progesterone, which was isolated as $20 \beta$-dihydroprogesterone, and androstenedione were demonstrated to be radiochemically pure by recrystallization to constant specific activity (Table 2). However, attempts to recrystallize $17 \alpha$ -

Table 1. Percentage of $\left[{ }^{3} \mathrm{H}\right]$ pregnenolone metabolized ( \pm s.d., no. of observations in parentheses) to product by skunk $\mathrm{CL}$

\begin{tabular}{|c|c|c|c|c|c|}
\hline Product & $\begin{array}{l}\text { Incubation } \\
\text { time (min) }\end{array}$ & Blank & Blood cells & 'Delay' CL & Activated CL \\
\hline $\begin{array}{l}\text { Progesterone } \\
(62 \%)^{*}\end{array}$ & $\begin{array}{r}10 \\
30 \\
60 \\
180\end{array}$ & $\begin{array}{l}{ }^{\mathrm{a}} 0.1 \pm 0.1(2) \\
{ }^{\mathrm{a}} 0.1 \pm 0.2(5) \\
{ }^{\mathrm{a}} 0.0(4) \\
{ }^{\mathrm{a}} 0.1 \pm 0.1(7)\end{array}$ & $\begin{array}{l}{ }^{\mathrm{a}} 0.1 \pm 0.1(3) \\
{ }^{\mathrm{a}} 0.0(4) \\
{ }^{\mathrm{a}} 0.1 \pm 0.1(5) \\
{ }^{\mathrm{a}} 0.1 \pm 0.1(7)\end{array}$ & $\begin{array}{r}\mathrm{b}^{\mathrm{b}} 3.7 \pm 0.5(2) \\
\mathrm{b} 7.2 \pm 2.8(3) \\
\mathrm{b}_{22} 2.9 \pm 14.3(2) \\
\mathrm{b} 36.5 \pm 5.3(3)\end{array}$ & $\begin{array}{r}{ }^{\mathrm{a}} 2.6 \pm 2.2(2) \\
\mathrm{b} 7.5 \pm 2.8(4) \\
\mathrm{b} 12.9 \pm 2.2(3) \\
\mathrm{b} 36.7 \pm 12.4(5)\end{array}$ \\
\hline $\begin{array}{l}\text { Androstenedione } \\
(46 \%)^{*}\end{array}$ & $\begin{array}{r}10 \\
30 \\
60 \\
180\end{array}$ & $\begin{array}{l}{ }^{\mathrm{a}} 0.2 \pm 0.1(2) \\
{ }^{\mathrm{a}} 0.1 \pm 0.1(4) \\
{ }^{\mathrm{a}} 0.2 \pm 0.2(5) \\
{ }^{\mathrm{a}} 0.3 \pm 0.3(7)\end{array}$ & $\begin{array}{l}{ }^{\mathrm{a}} 0.1 \pm 0.2(2) \\
{ }^{\mathrm{a}} 0.1 \pm 0.1(4) \\
{ }^{\mathrm{a}} 0.0(5) \\
{ }^{\mathrm{a}} 0.0(6)\end{array}$ & $\begin{array}{l}{ }^{\mathrm{a}} 0.0(2) \\
{ }^{\mathrm{a}} 0.1 \pm 0.0(2) \\
{ }^{\mathrm{b}} 0.4 \pm 0.2(3) \\
{ }^{\mathrm{b}} 0.9 \pm 0.3(2)\end{array}$ & $\begin{array}{l}{ }^{\mathrm{a}} 0.2 \pm 0.1(2) \\
\mathrm{b} 0.6 \pm 0.5(4) \\
\mathrm{b}_{0} 0.4 \pm 0.3(3) \\
\mathrm{b} 0.5 \pm 0.3(5)\end{array}$ \\
\hline $\begin{array}{l}\text { Testosterone } \\
\left(63^{\%} \%\right)^{*}\end{array}$ & $\begin{array}{r}60 \\
180\end{array}$ & $\begin{array}{l}{ }^{\mathrm{a}} 0.2 \pm 0.1(3) \\
{ }^{\mathrm{a}} 0.2 \pm 0.2(3)\end{array}$ & $\begin{array}{l}\mathrm{a} 0.0(2) \\
{ }^{\mathrm{a}} 0.0 \pm 0.1(3)\end{array}$ & $\begin{array}{l}{ }^{\mathrm{b}} 0.3 \pm 0.2(3) \\
\mathrm{b}_{0} 0.6 \pm 0.2(3)\end{array}$ & \\
\hline $\begin{array}{l}\text { 17 } \alpha \text {-OH pregnenolone } \\
\left(76^{\circ} \%\right)^{*}\end{array}$ & $\begin{array}{r}10 \\
30 \\
60 \\
180\end{array}$ & $\begin{array}{l}\mathrm{a} 0.3 \pm 0.2(3) \\
{ }^{\mathrm{a}} 0.3 \pm 0.2(3) \\
\mathrm{a} 0.1 \pm 0.1(5) \\
\mathrm{a}_{0} 0.2 \pm 0.1(7)\end{array}$ & $\begin{array}{l}\mathrm{a} 0.2 \pm 0.1(2) \\
\mathrm{a} 0.3 \pm 0.1(4) \\
\mathrm{a} 0.1 \pm 0.1(4) \\
{ }^{\mathrm{a}} 0.2 \pm 0.1(7)\end{array}$ & $\begin{array}{l}{ }^{\mathrm{a}} 0.1 \pm 0(2) \\
{ }^{\mathrm{a}} 0.2 \pm 0(3) \\
\mathrm{b}^{\mathrm{b}} 1.0 \pm 0.2(3) \\
{ }^{\mathrm{b}} 2.2 \pm 0.5(3)\end{array}$ & $\begin{array}{l}{ }^{{ }^{b}} 0.8 \pm 0.7(2) \\
{ }^{\mathrm{b}} 1.0 \pm 0.4(4) \\
{ }^{b_{0}} 0.5 \pm 0.1(3) \\
{ }^{\mathrm{b}} 1.3 \pm 0.5(5)\end{array}$ \\
\hline
\end{tabular}

Different superscripts indicate significant differences $(P<0.05)$ across rows.

* Average recovery of product after chromatography and derivative formation. 
Table 2. Recrystallization of radiolabelled products isolated after incubation of skunk $\mathrm{CL}$ with $\left[{ }^{3} \mathrm{H}\right]$ pregnenolone

\begin{tabular}{|c|c|c|}
\hline $\begin{array}{l}\text { Recrystallization } \\
\text { number }\end{array}$ & $\begin{array}{l}\text { 20 } \beta \text {-Dihydroprogesterone acetate } \\
\text { (d.p.m. } / \mu \mathrm{g} \text { ) }\end{array}$ & $\begin{array}{l}\text { Androstenedione } \\
\text { (d.p.m./ } / \mu \mathrm{g})\end{array}$ \\
\hline 1 & $14 \cdot 7($ pentane : benzene $v / v)$ & 5.5 (pentane : acetone) \\
\hline 2 & 14.8 (petroleum ether : benzene $\mathrm{v} / \mathrm{v})$ & 3.4 (benzene : acetone) \\
\hline 3 & $15.5\left(\mathrm{MeOH}: \mathrm{H}_{2} \mathrm{O}\right)$ & 3.6 (pentane : acetone) \\
\hline 4 & $15 \cdot 2\left(\mathrm{MeOH}: \mathrm{H}_{2} \mathrm{O}\right)$ & 3.5 (benzene : acetone) \\
\hline 5 & 14.9 (acetone : $\mathrm{MeOH}$ ) & \\
\hline
\end{tabular}

Table 3. Percentage of $\left[{ }^{3} \mathrm{H}\right]$ progesterone metabolized ( \pm s.d., no. of observations in parentheses) to product by skunk $\mathrm{CL}$

\begin{tabular}{|c|c|c|c|c|c|}
\hline Product & $\begin{array}{l}\text { Incubation } \\
\text { time (min) }\end{array}$ & Blank & Blood cells & 'Delay' CL & Activated $\mathrm{CL}$ \\
\hline $\begin{array}{l}\text { 20 } \alpha \text {-Dihydroprogesterone } \\
(56 \%)^{*}\end{array}$ & $\begin{array}{r}30 \\
60 \\
180\end{array}$ & $\begin{array}{l}{ }^{\mathrm{a}} 0 \cdot 0(7) \\
{ }^{\mathrm{a}} 0 \cdot 0(4) \\
\mathrm{a} 0 \cdot 0(8)\end{array}$ & $\begin{array}{l}{ }^{a} 0.0(8) \\
{ }^{a} 0.0(3) \\
{ }^{a} 0.0(9)\end{array}$ & $\begin{array}{c}\mathrm{a}_{0} 0 \cdot 0(3) \\
{ }^{\mathrm{a}} 0 \cdot 0(2) \\
\mathrm{b} 0 \cdot 2 \pm 0 \cdot 1(2)\end{array}$ & $\begin{array}{l}{ }^{a} 0 \cdot 0(5) \\
{ }^{a} 0 \cdot 0(4) \\
{ }^{a} 0 \cdot 0(4)\end{array}$ \\
\hline $\begin{array}{l}\text { 17 } \alpha \text {-Hydroxyprogesterone } \\
(48 \%)^{*}\end{array}$ & $\begin{array}{r}30 \\
60 \\
180\end{array}$ & $\begin{array}{l}\mathrm{a} 0.4 \pm 1.0(7) \\
\mathrm{a} 0 \cdot 1 \pm 0.2(4) \\
\mathrm{a} 0 \cdot 1 \pm 0.1(6)\end{array}$ & $\begin{array}{c}{ }^{\mathrm{a}} 0 \cdot 0 \pm 0 \cdot 1(8) \\
{ }^{\mathrm{a}} 0 \cdot 0(4) \\
{ }^{\mathrm{a}} 0 \cdot 1 \pm 0 \cdot 1(8)\end{array}$ & $\begin{array}{l}a 0.7 \pm 0.2(3) \\
03.0 \pm 0.5(2) \\
07.5 \pm 0.7(2)\end{array}$ & $\begin{array}{l}{ }^{a} 0 \cdot 6 \pm 0.7(5) \\
{ }^{a} 0 \cdot 5 \pm 0 \cdot 1(4) \\
{ }^{b} 1.3 \pm 2 \cdot 2(4)\end{array}$ \\
\hline
\end{tabular}

Different superscripts indicate significant differences $(P<0.05)$ across rows.

* Average recovery of product after chromatography and derivative formation.

hydroxypregnenolone and testosterone to constant specific activity were not successful due to lack of sufficient ${ }^{3} \mathrm{H}$-labelled product.

Small amounts of $17 \alpha$-hydroxyprogesterone $(P<0.05)$ accumulated after incubating 'delay' and activated $\mathrm{CL}$ with $\left[{ }^{3} \mathrm{H}\right]$ progesterone (Table 3 ). The amount of $20 \alpha$-dihydroprogesterone accumulated after incubating 'delay', but not activated $\mathrm{CL}$, with $\left[{ }^{3} \mathrm{H}\right]$ progesterone was very low but statistically significant $(P<0.05)$. Metabolism of $\left[{ }^{3} \mathrm{H}\right]$ progesterone to $5 \alpha$-dihydroprogesterone, androstenedione and testosterone did not occur in significant quantities $(P>0.05)$ (data not presented). Recoveries of various steroid products which accumulated after incubation with progesterone varied from 48 to $75 \%$. Sufficient amounts of $\left[{ }^{3} \mathrm{H}\right] 20 \alpha$-dihydroprogesterone or $\left[{ }^{3} \mathrm{H}\right]$ $17 \alpha$-hydroxyprogesterone were not available for recrystallization.

Androstenedione was the major metabolite recovered after incubating CL from skunks with diapausing and activated blastocysts with $\left[{ }^{3} \mathrm{H}\right] \mathrm{DHEA}: 34-46 \%$ of the total radioactivity added had accumulated in this product after $180 \mathrm{~min}$ of incubation (Table 4 ). The $\left[{ }^{3} \mathrm{H}\right]$ androstenedione was shown to be radiochemically pure by recrystallization to constant specific activity (data not shown). Small but significant $(P<0.05)$ quantities of $\left[{ }^{3} \mathrm{H}\right]$ oestrone also accumulated after incubating activated CL but not 'delay' $\mathrm{CL}$ with $\left[{ }^{3} \mathrm{H}\right]$ DHEA (Table 4). The identity of this product was not verified by recrystallization because all of the product was used for quantification purposes. There was no evidence that $\left[{ }^{3} \mathrm{H}\right] \mathrm{DHEA}$ was converted to androstenediol although the average recovery for this product was high $(61 \%$, data not shown).

$\left[{ }^{3} \mathrm{H}\right]$ Testosterone was metabolized to oestradiol-17 $\beta$ in low but significant $(P<0.05)$ amounts by activated skunk CL (Table 5). A similar test for the presence of aromatase activity was not conducted with 'delay' $\mathrm{CL}$ because insufficient tissue was available. The $\left[{ }^{3} \mathrm{H}\right]$ oestradiol recovered was demonstrated to be radiochemically pure by recrystallization to constant specific activity (data not shown). 
Table 4. Percentage of $\left[{ }^{3} \mathrm{H}\right]$ dehydroepiandrosterone metabolized ( \pm s.d., no. of observations in parentheses) to product by skunk CL

\begin{tabular}{|c|c|c|c|c|c|}
\hline Product & $\begin{array}{l}\text { Incubation } \\
\text { time (min) }\end{array}$ & Blank & Blood cells & 'Delay' CL & Activated $\mathrm{CL}$ \\
\hline $\begin{array}{l}\text { Androstenedione } \\
\left(66^{\circ} \%\right)^{*}\end{array}$ & $\begin{array}{r}30 \\
60 \\
180\end{array}$ & $\begin{array}{l}{ }^{\mathrm{a}} 11.8 \pm 4.2(4) \\
{ }^{2} 5.4 \pm 2.0(7) \\
{ }^{2} 6.8 \pm 3.0(7)\end{array}$ & $\begin{array}{l}\text { a9.4 } \pm 6.0(2) \\
\text { a } 7.6 \pm 5.1(9) \\
\text { a } 5.8 \pm 1.5(10)\end{array}$ & $\begin{array}{l}\mathrm{b} 27 \cdot 6 \pm 8 \cdot 3(3) \\
\mathrm{b} 34.0 \pm 3 \cdot 3(3)\end{array}$ & $\begin{array}{c}{ }^{\mathrm{a}} 6.6 \pm 3.6(3) \\
\mathrm{b}_{1} 19.6 \pm 9.7(7) \\
{ }^{\mathrm{b}} 46.7 \pm 13.7(7)\end{array}$ \\
\hline $\begin{array}{l}\text { Oestrone } \\
(68 \%)^{*}\end{array}$ & $\begin{array}{r}30 \\
60 \\
180\end{array}$ & $\begin{array}{l}{ }^{\mathrm{a}} 0.0(10) \\
{ }^{\mathrm{a}} 0.0(8)\end{array}$ & $\begin{array}{c}{ }^{\mathrm{a}} 0 \cdot 0(3) \\
{ }^{\mathrm{a}} 0 \cdot 0 \pm 0 \cdot 1(9) \\
{ }^{2} 0 \cdot 0 \pm 0 \cdot 1(10)\end{array}$ & $\begin{array}{l}{ }^{a} 0.1 \pm 0.1(3) \\
{ }^{a} 0.1 \pm 0.1(3)\end{array}$ & $\begin{array}{l}\mathrm{a} 0.2 \pm 0.3(9) \\
{ }^{\mathrm{b}} 0.2 \pm 0.2(7) \\
\mathrm{b}_{0} 0.2 \pm 0.2(5)\end{array}$ \\
\hline
\end{tabular}

Different superscripts indicate significant differences $(P<0.05)$ across rows.

* Average recovery of product after chromatography and derivative formation.

Table 5. Percentage of $\left[{ }^{3} \mathrm{H}\right]$ testosterone metabolized $( \pm$ s.d., no. of observations in parentheses) to product by skunk $\mathrm{CL}$

\begin{tabular}{ccccc}
\hline Product & $\begin{array}{c}\text { Incubation } \\
\text { time (min) }\end{array}$ & Blank & Blood cells & Activated CL \\
\hline $\begin{array}{c}\text { Oestradiol } \\
(64 \%)^{*}\end{array}$ & 60 & ${ }^{\mathrm{a}} 0 \cdot 1 \pm 0 \cdot 0(3)$ & ${ }^{\mathrm{a}} 0 \cdot 1 \pm 0 \cdot 1(3)$ & $\mathrm{b} 0 \cdot 4 \pm 0 \cdot 1(3)$ \\
\hline
\end{tabular}

Different superscripts indicate significant differences $(P<0.05)$ across rows.

* Average recovery of product after chromatography and derivative formation.

Packed blood cells were used as an additional control due to the highly vascular nature of the CL. In all cases, steroid metabolism by blood cells was not significantly different $(P>0.05)$ from controls without luteal tissue or cells.

\section{Discussion}

The most prominent steroid enzyme in skunk luteal tissue was found to be $\Delta^{5}$ isomerase, $3 \beta$ hydroxysteroid dehydrogenase (3 $\beta$-HSD) because incubation of skunk CL with $\left[{ }^{3} \mathrm{H}\right]$ pregnenolone for $3 \mathrm{~h}$ resulted in $36 \%$ of the precursor accumulating as progesterone. Studies of the ferret revealed progesterone to be the major steroid present in the CL (Dimond, Buchanan, Belbeck, Murphy \& YoungLai, 1977). Earlier work with American badgers (Fevold \& Wright, 1969) and ferrets (Kintner \& Mead, 1983) demonstrated that CL produced large amounts of progesterone after incubation with $\left[{ }^{3} \mathrm{H}\right]$ pregnenolone. Our observation of high $3 \beta-\mathrm{HSD}$ activity in the skunk is therefore similar to the findings for badgers and ferrets. We found no evidence that progesterone was reduced to $5 \alpha$-dihydroprogesterone and negligible quantities of $20 \alpha$-dihydroprogesterone accumulated after 3-h incubations of 'delay' $C L$ only. Similar observations regarding $5 \alpha$-reductase and $20 \alpha$-hydroxydehydrogenase activities have been reported for ferret CL (Kintner \& Mead, 1983). Low plasma levels of $20 \alpha$-dihydroprogesterone were reported for mink, suggesting that this enzyme may not be very active in vivo (Murphy \& Moger, 1977). Another reaction catalysed by $3 \beta-$ HSD, the metabolism of DHEA to androstenedione, proceeded with approximately the same amount of product accumulating (34-46\%) as was observed in the conversion of pregnenolone to progesterone. These results suggest that if DHEA or androstenedione were made available from a non-luteal compartment of the ovary, they could be converted to testosterone or oestrogens within the CL. However, we found inconsistent evidence of $17 \beta$-hydroxysteroid dehydrogenase (17 $\beta$ HSD) activity: conversion of $\left[{ }^{3} \mathrm{H}\right] \mathrm{DHEA}$ to androstenediol did not occur and testosterone did not accumulate in incubations of $\mathrm{CL}$ with $\left[{ }^{3} \mathrm{H}\right]$ progesterone. Nevertheless, when $\mathrm{CL}$ were incubated 
with $\left[{ }^{3} \mathrm{H}\right]$ pregnenolone, $0 \cdot 3-0.6 \%$ of this precursor accumulated as testosterone, but this product failed to reach constant specific activity after 4 recrystallizations (data not shown). Had sufficient material remained for a 5 th crystallization it is quite likely that radiochemical purity of this product would have been demonstrated.

Kintner \& Mead (1983) also demonstrated a high percentage of conversion of [ $\left.{ }^{3} \mathrm{H}\right] \mathrm{DHEA}$ to androstenedione in ferret CL. Dimond et al. (1977) reported high levels of androstenedione in ferret $\mathrm{CL}$, but because the amount of androstenedione was estimated by radioimmunoassay, it is not known whether this was produced from $17 \alpha$-hydroxyprogesterone or DHEA. The fact that skunk CL readily metabolized DHEA to androstenedione suggests that the efficacy of androstenedione to induce implantation should be tested since androgens such as testosterone and $5 \alpha$-dihydrotestosterone can induce implantation in mice (Roy, SenGupta \& Manchanda, 1980). However, administration of three different doses of androstenedione to progesterone-primed ferrets ovariectomized on Day 6 of pregnancy failed to induce implantation by Day 13 (Kintner \& Mead, 1983). There is therefore reason to doubt whether this might be the luteal factor which acts in conjunction with progesterone to induce implantation in mustelids.

Metabolism of $\left[{ }^{3} \mathrm{H}\right]$ pregnenolone to $17 \alpha$-hydroxypregnenolone and $\left[{ }^{3} \mathrm{H}\right]$ progesterone to $17 \alpha-$ hydroxyprogesterone suggests the presence of $C_{21}$ steroid $17 \alpha$-hydroxylase in skunk CL. However, only very small quantities of these products accumulated. Minimal activity of this enzyme was also demonstrated in ferret CL (Kintner \& Mead, 1983). There was a lack of accumulation of DHEA from $17 \alpha$-hydroxypregnenolone and of androstenedione from $17 \alpha$-hydroxyprogesterone, suggesting that 17-20 desmolase might not be very active. However, the observation that $\left[{ }^{3} \mathrm{H}\right]-$ pregnenolone was converted to androstenedione suggests that this enzyme is indeed present in the skunk CL.

Aromatase activity, as estimated by measuring the accumulation of oestradiol- $17 \beta$ from $\left[{ }^{3} \mathrm{H}\right]$ testosterone, was present in activated CL. It has likewise been demonstrated that ferret CL contain this enzyme (Mead \& Swannack, 1980) and that the precursor (testosterone) is present in ferret CL collected on Days 6 and 8 of pregnancy (Mead \& McRae, 1982). Dimond et al. (1977) reported that significant quantities of androstenedione, testosterone and oestradiol were secreted into the culture medium during a 24-h incubation of ferret CL on Day 12 of pregnancy. Oestrogen levels measured throughout pregnancy in the spotted skunk ranged from 3 to $29 \mathrm{pg} / \mathrm{ml}$ and were lower a few days before implantation (3-8 $\mathrm{pg} / \mathrm{ml}$ ) than during the preceding period of embryonic diapause (Ravindra \& Mead, 1984). Although oestrogen has been demonstrated to be an essential factor for implantation in the rat and mouse (Weichert, 1942; Cochrane \& Meyer, 1957; Smithberg \& Runner, 1960; Yoshinaga, 1961; Harper \& Walpole, 1967), there is no evidence that oestrogen is required to induce implantation in any carnivore. The initiation of implantation with oestrogen or a combination of progesterone and oestrogen has so far failed in weasels (Wright, 1963; Shelden, 1973), European badger (Canivenc, 1966), mink (Cochrane \& Shackelford, 1962), and ferrets (Wu \& Chang, 1972, 1973; Mead \& McRae, 1982). Murphy \& Mead (1976) could not inhibit implantation in ferrets by daily injections of high titre oestrogen antibody on Days 3-13 of pregnancy.

It could be argued that the only enzyme ( $3 \beta-H S D)$ which was observed to be highly active requires NAD whereas all the other enzymes, which require NADPH, exhibited lesser activity because inadequate NADPH was synthesized by luteal tissue in the absence of glucose in the medium. However, NADPH could not have been exhausted otherwise we would not have observed increased synthesis of products such as $17 \alpha$-hydroxypregnenolone (Table 1) and 17 $\alpha$-hydroxyprogesterone (Table 3) with increased time of incubation.

Packed skunk blood cells were incubated as additional controls due to the highly vascular nature of the CL. Steroid metabolism by blood cells was not observed, suggesting that blood cells trapped within skunk CL do not contribute significantly to steroid metabolism. This finding differs slightly from the observations of Kintner \& Mead (1983) who reported that ferret blood cells exhibited $20 \alpha$-hydroxydehydrogenase and $5 \alpha$-reductase activity. 
The present study did not reveal any dramatic differences in steroid metabolism by CL during the two periods of pregnancy investigated. We do not believe this is due to inappropriate classification of the two types of CL. Prior studies have convincingly demonstrated that skunk blastocysts with diameters of $<1.2 \mathrm{~mm}$ exhibit more depressed protein synthesis (Rourke \& Mead, 1982) and RNA synthesis (unpublished observations) than those with larger diameters. The majority of animals in this study classified as activated had blastocyst diameters of $\geqslant 1.6 \mathrm{~mm}$. Based upon empirical observations, we estimate that such blastocysts are less than 3 days away from implantation. Moreover, earlier studies suggest that morphological and biochemical changes in skunk CL can be detected several days before implantation (Sinha \& Mead, 1975, 1976; Mead, 1981). Our results do not readily suggest which steroid(s) (in conjunction with progesterone) could be candidates for the unknown luteal factor which is believed to induce implantation in the skunk. In fact, these results could be interpreted as suggesting that the luteal factor is not a steroid.

This study was supported by a grant from the National Institutes of Child Health and Human Development (HD 06556). We thank Ms Peggy Kintner and Martha McRae for excellent technical assistance and Ms Linda Florence for typing the manuscript.

\section{References}

Brown, J.B. (1955) A chemical method for the determination of oestriol, oestrone, and oestradiol in human urine. Biochem. J. 60, 185-193.

Canivenc, R. (1966) A study of progestation in the European badger (Meles meles L.). Symp. zool. Soc. Lond. 15, 15-26.

Cochrane, R.L. \& Meyer, R.K. (1957) Delayed implantation in the rat induced by progesterone. Proc. Soc. exp. Biol. Med. 96, 155-159.

Cochrane, R.L. \& Shackelford, R.M. (1962) Effects of exogenous oestrogen alone and in combination with progesterone on pregnancy in the intact mink. $J$. Endocr. 25, 101-106.

Dimond, P., Buchanan, G.D., Belbeck, L.W., Murphy, B.D. \& YoungLai, E.V. (1977) Steroidogenesis in ovarian compartments of the ferret at estrus and pregnancy. IRCS, Med. Sci. 5, 56.

Fevold, R.H. \& Wright, P.L. (1969) Steroid metabolism by badger (Taxidea taxus) ovarian tissue homogenates. Gen. comp. Endocr. 13, 60-67.

Foresman, K.R. \& Mead, R.A. (1978) Luteal control of nidation in the ferret (Mustela putorius). Biol. Reprod. 18, $490-496$.

Harper, M.J.K. \& Walpole, A.L. (1967) Mode of action of I.C.I. 46,474 in preventing implantation in rats. $J$. Endocr. 37, 83-92.

Kintner, P.J. \& Mead, R.A. (1983) Steroid metabolism in the corpus luteum of the ferret. Biol. Reprod. 29 , $1121-1127$.

Mead, R.A. (1968) Reproduction in western forms of the skunk (genus Spilogale). J. Mammal. 49, 373-390.

Mead, R.A. (1981) Delayed implantation in Mustelidae, with special emphasis on the spotted skunk. $J$. Reprod. Fert., Suppl. 29, 11-24.

Mead, R.A. \& Eik-Nes, K.B. (1969) Seasonal variation in plasma levels of progesterone in western forms of the spotted skunk. J. Reprod. Fert., Suppl. 6, 397-403.

Mead, K.A. \& McRae, M. (1982) Is estrogen required for implantation in the ferret? Biol. Reprod. 27, 540-547.
Mead, R.A. \& Swannack, A. (1980) Aromatase activity in corpora lutea of the ferret. Biol. Reprod. 22, 560-565.

Mead, R.A., Concannon, P.W. \& McRae, M. (1981) Effect of progestins on implantation in the western spotted skunk. Biol. Reprod. 25, 128-133.

Murphy, B.D. \& Mead, R.A. (1976) Effects of antibodies to oestrogens on implantation in ferrets. J. Reprod. Fert. 46, 261-263.

Murphy, B.D. \& Moger, W.H. (1977) Progestins of mink gestation: the effects of hypophysectomy. Endocrine Res. Commun. 4, 45-60.

Murphy, B.D., Mead, R.A. \& McKibbin, P.E. (1983) Luteal contribution to the termination of preimplantation delay in mink. Biol. Reprod. 28, 497-503.

Ravindra, R. \& Mead, R.A. (1984) Plasma estrogen levels during pregnancy in the western spotted skunk. Biol. Reprod. 30, 1153-1159.

Rourke, A.W. \& Mead, R.A. (1982) Blastocyst protein synthesis during obligate delay of implantation and embryo activation in the western spotted skunk. $J$. exp. Zool. 221, 87-92.

Roy, S.K., SenGupta, J. \& Manchanda, S.K. (1980) Induction of implantation by androgens in mice with delayed implantation. J. Reprod. Fert. 58, 339-343.

Shelden, R.M. (1973) Failure of ovarian steroids to influence blastocysts of weasels (Mustela erminea) ovariectomized during delayed implantation. Endocrinology 92, 638-641.

Sinha, A.A. \& Mead, R.A. (1975) Ultrastructural changes in granulosa lutein cells and progesterone levels during preimplantation, implantation, and early placentation in the western spotted skunk. Cell Tiss. Res. 164, 179-192.

Sinha, A.A. \& Mead, R.A. (1976) Morphological changes in the trophoblast, uterus and corpus luteum during delayed implantation and implantation in the western spotted skunk. Am. J. Anat. 145, 331-356.

Smithberg, M. \& Runner, M.N. (1960) Retention of blastocysts in nonprogestational uteri of mice. J. exp. Zool. 143, 21-31. 
Weichert, C.K. (1942) The experimental control of prolonged pregnancy in the lactating rats by means of estrogen. Anat. Rec. 83, 1-17.

Wright, P.L. (1963) Variations in reproductive cycles in North American mustelids. In Delayed Implantation, pp. 77-97. Ed. A. C. Enders. University of Chicago Press.

Wu, J.T. \& Chang, M.C. (1972) Effects of progesterone and estrogen on the fate of blastocysts in ovari- ectomized pregnant ferrets : a preliminary study. Biol. Reprod. 7, 231-237.

Wu, J.T. \& Chang, M.C. (1973) Hormonal requirement for implantation and embryonic development in the ferret. Biol. Reprod. 9, 350-355.

Yoshinaga, K. (1961) Effect of local application of ovarian hormones on the delay in implantation in lactating rats. J. Reprod. Fert. 2, 35-41.

Received 19 March 1984 